\title{
Interrupting the Anthropo-obScene
}

DOI:

$10.1177 / 0263276418757314$

\section{Document Version}

Accepted author manuscript

Link to publication record in Manchester Research Explorer

\section{Citation for published version (APA):}

Swyngedouw, E., \& Ernstson, H. (2018). Interrupting the Anthropo-obScene: Immuno-biopolitics and Depoliticizing More-than-Human Ontologies in the Anthropocene. Theory, Culture \& Society, 35(6), 3.

https://doi.org/10.1177/0263276418757314

\section{Published in:}

Theory, Culture \& Society

\section{Citing this paper}

Please note that where the full-text provided on Manchester Research Explorer is the Author Accepted Manuscript or Proof version this may differ from the final Published version. If citing, it is advised that you check and use the publisher's definitive version.

\section{General rights}

Copyright and moral rights for the publications made accessible in the Research Explorer are retained by the authors and/or other copyright owners and it is a condition of accessing publications that users recognise and abide by the legal requirements associated with these rights.

\section{Takedown policy}

If you believe that this document breaches copyright please refer to the University of Manchester's Takedown Procedures [http://man.ac.uk/04Y6Bo] or contact uml.scholarlycommunications@manchester.ac.uk providing relevant details, so we can investigate your claim.

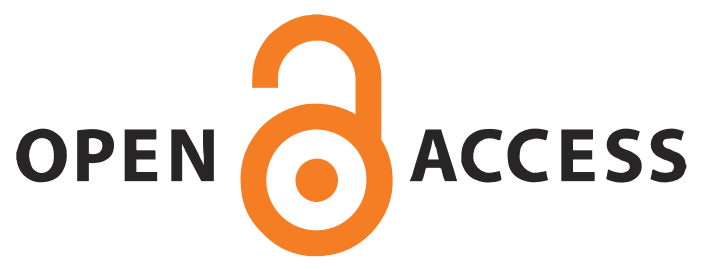


This manuscript was accepted for publication on 21 Nov 2017 in the journal Theory, Culture and Society. This version is the last version we submitted. Please contact the authors for how to reference, erik.swyngedouw@manchester.ac.uk or ernstson@kth.se, or check TCS's website. For now, you can use:

Swyngedouw, Erik and Henrik Ernstson (2018, in press) Interrupting the Anthropo-obScene: ImmunoBiopolitics and Depoliticizing More-than-Human Ontologies in the Anthropocene. Theory, Culture \& Society. Accepted for publication on 21 Nov 2017.

\section{Interrupting the Anthropo-obScene:}

\section{Immuno-biopolitics and Depoliticising Ontologies in the Anthropocene}

Erik Swyngedouw (*) and Henrik Ernstson $(* *, * * *)$

(*) Department of Geography, The University of Manchester (erik.swyngedouw@manchester.ac.uk)

(**) Department of Geography, The University of Manchester (henrik.ernstson@manchester.ac.uk)

(***) KTH Environmental Humanities Laboratory, Division of History of Science, Technology and Environment, KTH Royal Institute of Technology, Stockholm

\footnotetext{
Abstract

This paper argues that 'the Anthropocene' is a deeply depoliticizing notion. This depoliticization unfolds through the creation of a set of narratives, what we refer to as 'AnthropoScenes', which broadly share the effect of off-staging certain voices and forms of acting. Our notion of the Anthropo-obScene is our tactic to both attest to and undermine the depoliticizing stories of 'the Anthropocene'. We first examine how various AnthropoScenes, while internally fractured and heterogeneous, ranging from
} 
geo-engineering and Earth System science to more-than-human and object oriented ontologies, places things and beings, human and non-human, within a particular relational straitjacket that does not allow for a remainder or constitutive outside. This risks deepening an immunological bio-political fantasy that promises adaptive and resilient terraforming, an earth system management of sorts that permits life as we know it to continue for some, while turning into a necropolitics for others. Second, we develop a post-foundational political perspective in relation to our dramatically changing socioe-cological situation. This perspective understands the political in terms of performance and, in an Arendtian manner, re-opens the political as forms of public-acting in common that subtracts from or exceeds what is gestured to hold socio-ecological constellations together. We conclude that what is off-staged and rendered obscene in 'the AnthropoScenes' carries precisely the possibility of a return of the political.

\section{Introduction}

One possible origin of the word obscene derives from classical Greek theatre. The 'skene' was the structure behind the stage with internal rooms hidden from the audience and from where actors emerged to narrate the story. However, some acts had to remain off-stage, $o b$-skene, as they were deemed inappropriate to be shown explicitly. This included sexual conduct, violence, and death, but also emotions of deep anguish and fear. Nonetheless, the spectator was uncannily aware of their disturbing subterranean presence. It is from this perspective that we mobilize the somewhat awkward term 'the Anthropo-obScene,' which we place in a troubling relation to the now popularized notion of 'the Anthropocene'. 
In this contribution, we shall use 'the Anthropocene' to denote the proposed new geological era during which humans have arguably acquired planetary geophysical agency, a term increasingly mobilized by geologists, Earth Systems scientists and scholars from the humanities and social science. While recognizing a wideranging and often contentious debate (see e.g. Castree, 2014a, 2014b, 2014c; Hamilton, Bonneuil and Gemenne, 2015), we hold that the Anthropocene is a deeply depoliticizing notion that off-stages political possibilities. This off-staging unfolds, we contend, through the creation of what we refer to as 'AnthropoScenes', the miseen-scene of a particular set of narratives that are by no means homogeneous, but which broadly share the effect of off-staging certain voices and forms of acting. Our notion of the Anthropo-obScene then, is our tactic to both attest to and undermine the performativity of the depoliticizing stories of 'the Anthropocene'; a hacking of a popularized term to render sensible its uncanny underbelly.

We shall deploy this term through two broader registers. First, we examine how the AnthropoScenes can be viewed as a set of stages that have constructed and variably engaged the signifier 'Anthropocene'. While internally fractured and heterogeneous - ranging from those promoting geo-engineering and Earth System science as an immunological prophylactic to our situation, to interlocutors developing more-than-human and object oriented ontologies in search of a new politics - there is an uncanny effect of placing things and beings, human and non-human, within a particular relational straitjacket that does not allow for a remainder or constitutive outside. Such relational ontology tolerates no excess, subtraction, or supernumerary. This gesture risks precisely to off-stage the political. Second, building on postfoundational political thought, we shall articulate in theoretical terms what is being censored and rendered obscene, and how foregrounding what is off-staged may hold 
possible paths toward re-politicization. We mobilize theoretical perspectives that have attempted to cut through the last decades of pervasive de-politicization. These views understand the political in terms of performance and, in an Arendtian manner, as constituted through a space of appearance, a performative public acting-in-common that politicizes subjects and spaces (Arendt, 1958: 199). From this perspective, the political is understood as forms of acting subtracted from or excessive to what is gestured to hold socio-ecological constellations together. In other words, the political is manifested in forms of supernumerary acting that exceeds the internal relational assemblage from which it emerges. Put simply, 'the political' is the signifier that stands for the immanent rupturing of relations, thereby exploding the myth of the possibility of a closed relational configuration. In sum, the paper critically examines the potentially depoliticizing implications of a political ontology proposed by a range of new materialist and more-than-human perspectives in the absence of a critical ontology of the political (see also, for example, Pellizoni, 2015).

The paper is organized in three parts. In the first part, we examine how various AnthropoScenes, despite great debate and important differences, share two key characteristics. Each comes with its own disavowals and silences. First, the view that the inauguration of the 'Anthropocene' announces a rupture, a before and after its founding moment (contested as it may be), suggesting a radical 'newness' in the state of the situation. Second, the view that the AnthropoScenes implicitly or explicitly embrace a new more-than-human ontological perspective, one that foregrounds a horizontal relational materiality of how humans and non-humans are enmeshed. We interrogate how versions of such symmetrical relational ontologies, variously referred to as more-than-human or object-oriented ontologies, fuel a new cosmology, a new ordering of socio-natural relations (Stengers, 2003; Latour, 2005; Braun and 
Whatmore, 2010; Coole and Frost, 2010; Morton, 2013; Harman, 2016). We contend that this in turn opens the spectre (albeit by no means necessarily or intentionally so) for a deepening of a hyper-accelerationist eco-modernist vision in which big science, geo-engineering, and big capital can gesture to save both earth and earthlings (Neyrat, 2016). In the second part, we examine the implications of these new ontologies and question their radical political presumptions (Pellizzoni, 2015), further demonstrating how they resonate with a biopolitical frame of immunization, a form of governing that secures the life of some while sacrificing others. This immunological bio-political fantasy, we contend, depoliticizes matters, making sure that capitalist civilization as we know it can continue a while longer. It sustains promises of adaptive and resilient terraforming, an earth system management of sorts that permits life as we know it to continue for some, while turning into a necropolitics for others. In the third part, we return to examining the particular relational ontology on which object-oriented ontologies are based in order to examine how the disavowal of exteriority, combined with an impoverished notion of what constitutes 'the political' intensifies already deeply de-politicizing processes. We conclude by making a case for a return of the political through an ontology that strictly works with a relationality that recognizes excess and subtraction. We argue that all relationalities, such as patriarchy, capitalism, colonialism, and 'the Anthropocene', are dependent on excess and subtraction, which can, when made visible and sensible (as has been done in feminist, proletarian, subaltern, queer politics) open a politicizing procedure. There is indeed a possibility to re-cast the depoliticized story of the Anthropocene, and through that, to explore the contours of re-politicizing the socio-environmental conundrum we are in, while fully embracing humans' interdependence with non-humans. Drawing on postfoundational political thought, this perspective recognizes exteriority and separation 
as the condition of possibility for interdependence and relationality. It holds that all relational configurations imply a certain separation and distancing, and, thereby, the always-immanent possibility of forms of acting that undermine, transform, or supersede existing relational configurations.

In sum, our main objectives are: (i) to excavate the de-politicizing underbelly of much of Anthropocene-talk with a particular focus on post-human ontologies; (ii) to demonstrate how these new horizons potentially permit a further deepening, while transforming, capitalist forms of socio-natural assembling and thereby securing capital's hold over life; and (iii) to argue how a re-thinking of the relational socionatural configuration might inaugurate emancipatory forms of politicization.

\section{AnthropoScenes: Staging the Anthropocene}

The Anthropocene argument fully recognizes the active role of humans in coconstructing the earth's deep geo-historical time. But it also inaugurates a new ontological framing of relational symmetry between humans and non-humans. This double movement is what Christophe Bonneuil and Jean-Baptiste Fressoz (2013; 2016) have called 'the event of the Anthropocene.' Yesterday's ontology was, or so the Anthropocene argument goes, predicated upon externalizing Nature in a manner that nurtured humans' mastering over Nature (while nonetheless increasingly socializing the non-human). The inauguration of the modern nature-society split allegedly muted Nature while subordinating it to the whims and wills of a fastforwarding capitalist modernity. In contrast to this, the Anthropocene ostensibly announces a more modest and horizontal ontology, an immanent and indeterminate process of co-shaping heterogeneous socio-natural imbroglios. This then opens the promise of a mutually supporting and diversified nurturing of human-non-human 
constellations.

The notion of the Anthropocene implies an AnthropoScene, the staging of a narrative (or set of narratives) with profound implications that requires careful attention (see Bonneuil and Fressoz, 2016; Malm and Hornborg, 2014). They offer a range of alternative narratives such as, amongst others, thermocene, thanatocene, phagocene, capitalocene, and polemocene. Likewise, Jason Moore $(2015 ; 2016)$ suggests the notion of the Capitalocene, the age of capital. For him, the culprit is the expansive historical and geographical process of capitalist economic-political organization that operates within nature's web of life and which includes colonialism, industrialization, and globalization; TJ Demos (2015) develops the Gynocene, locating geological violence within patriarchal domination and sketches a feminist and gender-equal environmentalism; and Donna Haraway (2016), in a more positive naming of our epoch as the Chthulecene, shifts the focus toward inter-species collaborations and the 'sym-poiesis' of co-becoming that structures the very conditions of life. None of these scholars, including ourselves, can escape what William Cronon (1992) remarked already more than twenty years ago. He argued that any re-presentation of environmental history implies a storyline with its theatrical setting that stages a particular cast of key actors, agents, props, and relations while inevitably excluding other potential performers and relations. It is with this Crononian injunction in mind that we try, in the next section, to chart the underbelly of the AnthropoScenic stage-set.

\subsection{A Temporal Disjuncture? Enrolling Revisionist Geo-history}

The notion of the Anthropocene resonates widely among scientific and lay publics alike. Its appeal and rapid proliferation, from discussions among climate change 
scientists, environmental humanists and artists, to a catchword among observers, politicians and activists, has become a key diagnostic of our time and shapes ideas for future courses of action (Castree, 2014b; Lorimer, 2016). Across these widely different AnthropoScenes, which we recognize as distinct and internally conflicting, we hold that several of them share and thrive upon a peculiar temporal disjuncture that splits modernity into two - the before and after. Indeed, and irrespective of the ongoing debate over the exact moment of its inauguration (Steffen et al. 2011a; Lewis and Maslin, 2015), the event of the Anthropocene announces a presumably new socio-geo-physical era, one that recognizes that human kind, as a species, has acquired deep-time geological agency. This prompted Dipesh Chakrabarty (2009; 2017), amongst others (e.g. Yusoff, 2013; Clark, 2014; Erle et al., 2016), to call for a retroactive re-writing of the world's geo-environmental-cum-social history:

While freedom has been the most important motif of accounts of human history since the Enlightenment, there has never been an awareness of the geological agency human beings were gaining through processes linked to their acquisition of freedom. Whatever the rights we wish to celebrate as our freedom, we cannot afford to destabilize conditions that work like boundary parameters of human existence (Chakrabarty, 2009: 1).

In his call to re-write history, humans as a generic category have to be inserted in the world's geo-physical history as active agents in the making of their own combined earthly past and future. This relegates the 'modernist' split between humans and nature to an archaic view that needs to be left behind by constructing a new ontology based on a relational web of mutual determination — or so it seems. This kindling of a 
new ontology can be noted too in the AnthropoScenes that strictly follow technomanagerial and Earth System science approaches, narratives spun around 'Earth System Governance', 'Planetary Stewardship', and the 'good Anthropocene' (Biermann, 2007; Steffen et al., 2011b; Biermann et al., 2012), including ecomodernist notions of a geo-engineered terraformed earth (Shellenberger and Nordhaus, 2007; 2011). Political theorists, in turn, have called for a hyper-reflexive 'geopolitan democracy,' which takes into account human and non-human matters and their associational configuration (Eckersley, 2017). The reliance on a 'modernist split' can also be noted in Donna Haraway's Chthulucene's inter-species co-becoming (Haraway, 2016); in Timothy Morton's speculation with 'hyper-objects' (Morton, 2013); as well as in Bruno Latour's embrace of Gaia (Latour, 2015a, 2017). However, to insist on a modernist split and to call for a re-writing of the world's geo-social history radically obscures, silences and off-stages what has been an integral part of the modernist intellectual trajectory all along. As Locher and Fressoz put it:

By virtually denying the environmental awareness of past societies, [the Anthropocene] depoliticizes the long-term history of environmental deterioration while, by stressing the recent reflexivity as an intrinsic characteristic of our contemporary societies, such narratives tend to treat ecological concerns as a given and disregard the conflicts that have actually driven them. (Locher and Fressoz, 2012: 581)

The recognition of the role of humans as active agents of the earth's terraforming process has undeniably been a key ingredient of many a modernist vision and analytical framework (see, for example, Barnett, 2015). At least since the $18^{\text {th }}$ century, political economists and geo-scientists avant-la-lettre insisted on how human 
history is a history of rekindling the earth in an intimate relational articulation.

Consider, for example, Marx's famous statement from the Economic and

Philosophical Manuscripts of 1844:

Nature is man's inorganic body —nature, that is, insofar as it is not itself the human body. Man lives on nature-means that nature is his body, with which he must remain in continuous intercourse if he is not to die. That man's physical and spiritual life is linked to nature means simply that nature is linked to itself, for man is a part of nature (Marx, 1959 [1844]).

Charles Fourier lamented already in 1821 in his De la détérioration matérielle de la planète that 'climate disorders are a vice inherent to civilized culture' (cited in Bonneuil and Fressoz, 2016: 257; see also Fressoz and Locher, 2010; 2012). A more socio-ecological benign earth would require a transformation of this civilization. In fact, Bonneuil and Fressoz demonstrate how modernity has been marked by a continuous battle unfolding between on the one hand advocates of a sustained societynature dichotomy and man's manifest destiny to be master and commander of her external conditions of existence, and, on the other hand, proponents of a more modest and socio-ecologically sensitive mode of conduct and engagement. The long genealogy of intellectuals, who already in the $19^{\text {th }}$ century called for what we might now label as an AnthropoScenic storyline, one that emphasizes co-construction (see, for example, Marsh 1864, 1874; Sherlock 1922; Vernadsky 1926), continues to be scripted out and silenced, thereby skillfully forgetting — yet again — that the naturesociety split that is customarily deemed to belong uniquely to the singular core and backbone of modernization, signals just the ideological victory of one side in a fierce 
confrontation between radically opposing views (Fressoz, 2015; Neyrat, 2016; Bonneuil and Fressoz, 2016).

Across various AnthropoScenes, 'the event of the Anthropocene' is consequently staged as a moment of rupture of the temporality of modernity. But this (mis)represents modernity as monolithic and total, dividing its history in an unreflexive (pre-)modernity and a post-evental reflexive (post-)modernity, a simple before and after. This splits time and its geo-history into two. In doing so, modernization as an internally fractured and highly contentious process is off-staged. Its conflicting, socially heterogeneous, and politically contested — often interruptivetransformations become refracted into a singular and teleological understanding of the unfolding of modernity's history; and thus, one can argue, in a revisionist way, that we gained our freedoms by undermining Earth's 'boundary parameters'. What is disavowed is precisely modernity understood as the continuous confrontations and political conflicts over possible future trajectories in the context of dramatically changing socio-ecological situations. As Frédéric Neyrat attests:

Instead of a division of modernity between a before and an after [the event of the Anthropocene], a modernity initially ignorant, but later educated, it is a division in modernity that we need to consider. In place of a chronological division, a political division. (Neyrat, 2016: 117, our translation)

Modernity is not a single-headed process that now has been surpassed. On the contrary; it is the multi-headed internal struggle that predates as well as postdates the event of the Anthropocene. The risk with these AnthropoScenes, in spite of their internal differences, is the off-staging of the politics of dissensus that animated the 
historical-geographical dynamics of modernity.

\subsection{A Symmetrical Ontology and a New Cosmology}

While the process of off-staging varies across different AnthropoScenes, we maintain that the related emergence of a new cosmology could serve to deepen the process of capitalist enrolment of non-human and more-than-human processes. For example, the geo-sciences, and in particular Earth System experts have, despite acknowledging the limitation of their models and measurements, entertained a socially performative storyline that the advent of the Anthropocene inaugurates the possibility, if not necessity, for the management and careful 'adaptive' and 'resilient' massaging of the totality of the Earth System within its 'Planetary Boundaries'. Indeed, in their consensual rendering of the earth as an intricate, indeterminate, and complex intertwined socio-natural constellation, they have nonetheless opened up the promise that the earth can, with loving supervision, intelligent crafting, big-data monitoring, and careful techno-natural nurturing and manicuring, be terraformed to whatever socio-ecological condition humans may desire. One representative example of this promise revolves around geo-engineering. While internal debates proliferate over whether or not geo-engineering can or should become part of an adaptive earth system governance arrangement (Barrett et al., 2014), it is not excluded. Political scientist Victor Galaz, for instance, points out that '[e]arth stewardship and geo-engineering are not necessarily in conflict, but instead could be viewed as complementary approaches [to] combat climate change' (Galaz, 2012: 24). Crutzen himself insisted that the Anthropocene inaugurated a tectonic shift from engineering the socioecological relations in the interest of 'humanity', to the promises of a geo-engineering of the earth: 
This will require appropriate human behaviour at all scales, and may well involve internationally accepted, large-scale geo-engineering projects, for instance to 'optimize' the climate. (Crutzen, 2002: 23)

Much of this perspective is indebted to the consolidation of non-linear ecological complexity theory that cherishes 'emergence', 'resilience', continuous experimentation, the 'indeterminacy' of nature, and radical openness (Holling, 1973; Folke, 2006), but without explicit attention to capital, culture, and politics (see Nadasdy, 2007; Hornborg, 2009). As Bruce Braun (2015) insists, and drawing on Sara Nelson $(2014 ; 2015)$, we need to historically discern the parallel but contingent ways through which the non-deterministic geo-sciences (including complexity science and resilience theory) emerged alongside the new materialisms associated with morethan-human and object oriented ontologies (see also von Heland and Sörlin 2012; Ernstson and Sörlin 2013; Protevi, 2013; Pellizzoni, 2016a)[1]. Both rose to prominence in the context of the deep crisis of capitalism in the 1970s and its attempts to search for a fix to the malaise in the process of neoliberalization (see Walker and Cooper, 2011; Nelson, 2014; 2015). What is at stake here is precisely how a fastforwarding capitalist neoliberalization can proceed, despite or perhaps because of, an altered ontological premise, and with a storyline that masks what is really at stake. As Luigi Pellizzoni argues:

The main point is that the indeterminacy or constant becoming of matter and life, a decentred - post or anti-humanist — account of human agency and the contestation of any fundamental separation between matter and cognition are assumed by postconstructionist scholarship to have 'emancipatory' implications, for both human and 
nonhuman agents. If the building blocks of reality are not fixed—so the argument goes - politics becomes 'ontological' and novel opportunities for change open up. Targeted at the dualisms of naïve or Cartesian realism and of culturalism, however, this argument misses or downplays the politics of ontology inbuilt in the neoliberalization of nature, which builds precisely on these tenets. (Pellizzoni, 2015: 8)

It is here, in the adoption of a symmetrical and relational ontological displacement away from a human-centered ontology that various AnthropoScenes come together. This displacement has become a creative foundation from where various thinkers have searched for an allegedly post-capitalist politics that operates through horizontal, heterogeneous, and multi-species entanglements. This move stretches from post-industrial spaces where Anna Tsing (2015) has found laboratory environments where unexpected inter-species and organic-inorganic arrangements dwell, to the high Andean landscapes where Marisol de la Cadena (2015a: 3, 2015b) has carefully uncovered more-than-human collectivities that since the $16^{\text {th }}$ century have resisted 'a war waged against world-making practices that ignore the separation of entities into nature and culture'. In parallel, Deleuze and Guattari's immantism, often in dialogue with Isabelle Stengers' (2003) cosmopolitics, has served to articulate the experimental making of 'pluriform' inter-species entanglements, which for Jamie Lorimer and Clemens Driesen (2014) suggests a 'rewilding' of the world as exemplified by the Oostvaardersplassen experiment in the Netherlands. Dalby (2017) and Yusoff (2017) have re-considered geo-politics in light of humans' entanglement with geo-physical strata. Taking us deep into the mycelia of her Chthulucene, Donna Haraway (2016) has in turn called for making kin with all manner of heterogeneous siblings rather than gestate children for an already overpopulated (by humans) earth. 
Among these thinkers, we recognize that some have more explicitly foregrounded a ‘relative autonomy’ of non-humans, with Nigel Clark (2014), for example, developing a politics of ethical engagement and care as a consequence of the unpredictable, contingent, and often-erratic acting of non-humans. Our key point here, while recognizing crucial distinctions between different thinkers, is that symmetrical relational ontologies have not only served as common foundation for a fundamental rethinking of socio-environmental issues, but that they also stand guarantee for a postcapitalist politics. It is precisely this assumption we interrogate critically here.

This assumption of symmetrical ontological relations has indeed mobilized a new cosmology of earth and life that points to a new horizon beyond the present. Nonetheless, such radical re-scriptings have undoubtedly articulated with capital and neoliberalization in what Bruce Braun, after Elisabeth Provinelli, calls a 'strategic containment' of the more radical futures that symmetrical ontologies of the geosciences and post-human theories might hold (Braun, 2015). To put it bluntly, the immanentist ontology of earth's multifarious acting does not in itself guarantee a political transformation. That requires a re-thinking and re-enacting of the political too. Or in other words, not only do we need to on-stage the exteriority of the nonhuman, but also the exteriorities that cut through the human.

Despite its veil of radical newness that announces a departure from earlier modernity, interpretations of post-human thought could set the stage for a deepening of what capitalist modernization has pursued relentlessly since its inception. While in earlier dominant accounts, non-humans were considered to be recalcitrant, uncooperative, and prone to revengeful action when marshalled into capital's subordination and use (Bakker, 2004), a symmetrical ontology permits — at least in discourse and imaginary—a potentially more benign, mutually supporting, 
sustainable, and resilient assembling of human-non-human relations. This ontology would permit capitalism to propel forward to even greater heights of socio-ecological knotting while recognizing the acting and the incalculability of the non-human. The excessiveness, or supernumerary acting of 'nature' becomes enfolded within capitalism itself. To save the world and ourselves, we need not less capitalism, but a deeper, more intense and radically reflexive form of capitalism, one that revolves around reconstructing DNA and genetic material, forces gas out of shale formations so it can be 'carbon-stored' elsewhere, mobilizes the power of the nuclear to drive the economy, and works to terraform earth in a mutually benign co-constitution. Here we encounter the promise of a renewed and ecologically sensitive 'hyper-reflexive' capitalism that takes seriously both humans' geo-physical force and the material acting of the non-human, while redeeming the sins of the past. It is in this staging of the AnthropoScene, the 'good' Anthropocene, where the new symmetrical relational ontology could function as a philosophical quilt for sustaining and advocating accelerationist hyper-modernizing manifestos (see Ellis, 2011; Ellis et al., 2016; for a critique, see Hamilton, 2013; 2015b; Neyrat, 2014; 2016).

One of the most emblematic bearers of this view is The Breakthrough Institute and its intellectual advocates (Shellenberger and Nordhaus, 2007; 2011). For them and fellow eco-pragmatists (Brand, 2009), the intensified use of nuclear energy, shale gas, climatic geo-engineering, bio-engineering and the development of new ecotechno-machineries (based on sun, wind, and photosynthesis) points toward the promises unleashed by the Anthropocene (see Neyrat, 2016, for a detailed account)[2]. Indeed, accelerationist and geo-constructionist manifestos mobilize a reflexive horizontal relational understanding of society-nature. They endorse nature's radical contingencies, while making sure that the existing capitalo-parliamentary 
order, as Alain Badiou (2008) would call it, remains intact and unchallenged in its universalizing march. As Pellizoni maintains:

[T]he ontological turn accommodates both post-humanist and trans-humanist arguments, precautionary and proactionary outlooks, decelerationist and accelerationist claims. And, indeed, the difference between these positions seems to blur. This raises the question of the extent to which non-dualist ontologies help analyze divergences and unrecognized affinities between, for example, new materialist movements... and positions like those expressed by the 'Ecomodernist Manifesto', with their plea for an accelerated Anthropocene. (Pellizoni, 2016b)

In a rebuttal to the Breakthrough Institute's eco-modernist manifesto, Bruno Latour $(2011 ; 2015 a)$ could seemingly not go beyond a feeble 'love your monsters'. Only tender loving care of our produced techno-natural imbroglios can bring hope. Clive Hamilton's (2015b) critique too remains on the safe terrain of accusing these newly styled eco-modernizers of not properly grasping the cosmology of the posthuman turn and its ethico-political implications. While Latour and Hamilton might fully recognize the depoliticizing tenure of the 'good' Anthropocene (see Latour, 2015b), they disavow what is at stake politically and economically for the elites, namely, the socio-ecological survival of capitalist civilization on the one hand, and the way that symmetrical ontologies are being enrolled within its orbit on the other. While the Breakthrough Institute is one example, an earlier, and more institutionally recognized example is undoubtedly the UK's Royal Society 2009 Policy document, Geoengineering the Climate. Its usual mixture of Promethean promises and can-do fervor (The Royal Society, 2009) has been followed by a range of others (for a review, see Morton, 2015). 
Covering up the contradictions of capitalist eco-modernization, the apparently revolutionary new materialist ontologies offer new storylines, new symbolizations of the earth's past and future that can be corralled to help perform the ideological groundwork required to cover up the contradictions of capitalist eco-modernization and help perform the ideological groundwork required. Having come this far, we now turn our attention to how the Anthropocene becomes inserted within politics, the governing of things and people in common.

\section{The Injunction to Bio-political Happiness}

The staging of the AnthropoScenes opens up new promises. From modest, ethically inflected multi-species arrangements, to geo-engineering and geo-management perspectives that supposedly can manicure the dynamics of the earth system. The mainstream interpretation of nature's end, the recognition of an intimate and unbreakable symbiosis between human actions and biophysical processes, really does terminate nature; it suspends the split between humans and nature (Swyngedouw, 2016). In doing so, nature is finally completely aufgehoben, rendered null and void. Nonetheless, as Neyrat asserts, 'any relational configuration is asymmetrical, always to the advantage of a colonizing side at the expense of a subservient side - that is why we need a certain distance' (Neyrat, 2016: 34, our translation). If the old naturesociety split fuelled practices that put us onto a highway to Armageddon and the potential termination of human life, the spectre opened by the name of the Anthropocene promises humans' active co-construction of the earth's deep geophysical forces, a promise to turn the prospect of apocalyptic annihilation into the potential for sustaining civilization as we know it, provided that the right metabolic vehicles and the correct geo-engineered technical intermediaries are put into place. 
And in this AnthropoScene, humans are thought simultaneously as super-powerful subjects and powerless victims (Neyrat, 2016: 83), as both inside and outside.

In what follows, we shall first argue that the openings provided by horizontal relational ontological perspectives could permit reproducing and deepening the immunological desire upon which a (neo-)liberal biopolitical governance regime is predicated. This promise, and second, assumes nonetheless a strict symmetrical relationality that not any longer allows for a constitutive outside. It is a relationality that permits a phantasmagorical scripting of a fully socialized nature.

\subsection{The De-politicized Politics of the Anthropocene: An Immuno-biopolitical}

\section{Fantasy}

The storylines of the AnthropScenes provide for an apparently immunological prophylactic against the threat of an irremediable external and revengeful nature. They offer a symbolization of the desire of humanity to protect and to immunize itself from the vagaries of a more-than-human acting that has leapt out of the bounds in which the Cartesian dualism of Nature and Culture symbolically tried to cocoon it. With such a tempting offer, it seems understandable why the Anthropocene has been so successful as a signifier-popular and scientific, horrifying and promising, potentially radical, yet utterly reactionary.

Roberto Esposito's analysis of bio-political governmentality, enhanced by Fréderic Neyrat's psychoanalytical interpretation (Esposito, 2008; 2011; Neyrat, 2010), offers an analytical entry into this conundrum. Esposito's main claim expands on Michel Foucault's notion of biopolitical governmentality as the quintessential form of modern liberal governance. He demonstrates how this biopolitical frame is increasingly sutured by an immunological drive, a mission to seal off objects of 
government from possibly harmful intruders and recalcitrant outsiders that threaten bio-social integrity and security, if not sheer survival, of the population, and guarantees that life can continue to be lived. For Esposito, 'the more humans, as well as ideas, languages and technologies, communicate and are bound up with one another, the more necessary preventative immunization as counterweight becomes' until it becomes the coagulating point of contemporary life (Esposito, 2008: 60). In other words, extending the relational configuration intensifies the immunological drive.

'Immunological' has to be understood here as the suspension of the obligation of communal gift giving. This creates an asylum that suspends one's obligation to participate in the rights and obligations of the commons, of the community. The (neo)liberal injunction of individual freedom and choice is precisely the founding gesture of such an immunological bio-politics, i.e., the ring-fencing of the fragmented and individualized body from its insertion in the obligations and violence that bonds community life (Brossat, 2003) and is, therefore, deeply de-politicizing.

Immuno-politics are at work, for example, in Western practices around immigration, health, environment, or international terrorism. A rapidly expanding arsenal of soft and hard technologies is put in place in an ever-denser layering of immunological, technical, infrastructural, and institutional-legal dispositifs-from tighter immigration law and continuous surveillance to the actual construction of steel and concrete walls and barriers, and the proliferation of all sorts of camps and other militarized or policed enclosures. Eco-managerial practices too, articulated around resilience and adaptation, which populate ecological interventions, 'sustainable' technologies, and governance practices, seem precisely to re-enforce the immunological prowess of the immune system of the body politic against recalcitrant, 
if not threatening, outsiders (like $\mathrm{CO}_{2}$, waste, bacteria, refugees, viruses, ozone, hurricanes, financial crises, and the like) so that we can believe that life as we know it can continue. Immuno-biopolitics deepens biopolitical governance in an era of foundational uncertainty and recognized perpetual risk (Neyrat, 2008). With respect to the politics of climate change, Pierre-Oliver Garcia puts it as follows:

An immunitary power takes control of the risks, dangers and fragilities of individuals to make them live in a peaceful manner while obscuring any form of dissensus. (Garcia, 2015: 321, our translation)

Roberto Esposito $(2008 ; 2011)$ and Alain Brossat (2003) call this drive immunitary democracy. This is a socio-political configuration operating as an immunity system that guarantees not being touched, that promises immunization. It is a fantasy of a total protection and securitization of life, without exposure to 'risk', a prophylactic closure against the socio-physical relations that produces anxiety, uncertainty, and the risk for bodily disintegration. For Brossat, this is a dangerous fantasy, as the immunitary logic entails nothing else than the destruction of community, of being-in-common. It produces the exposed (the non-immunized) as the flipside of the immunized body, and leads to de-politicization where the immunized become mere spectators of the suffering of others from the cocoon of their sanctuary spaces (Brossat, 2003). What remains is hatred of the other or distanced compassion with her suffering as flipsides of immunitary distantiation (Kaika, 2017). Of course, as Neyrat (2008) insists, the immunitary dispositif does not really function, since the exposure to risks affects all, albeit not to the same extent.

In relation to refugees, (bio-)security, or economic-financial collapse, 
immuno-biopolitical gestures customarily succeed in trans-locating risks and fear of collapse and disintegration (while nurturing them all-the same) onto the terrain of a crisis to be managed or a situation to adapt to. However, in the face of existing combined and uneven socio-ecological catastrophe this immuno-biopolitical dispositif of crisis management is rapidly disintegrating (Parenti, 2011). Indeed, with respect to our socio-ecological condition, the standard technologies of neoliberal governance become increasingly ineffective in sustaining and nurturing the immuno-biopolitical desire that Esposito $(2008 ; 2011)$ points to and which Brossat (2003) develops further in his Immunitary Democracy. Few believe, for example, that the 1.5 Celsius degree threshold for the limiting global temperature rise, set by the 'international community', will be achieved, irrespective of the number of COP meetings to be held. Is it not the case that 'earth system governance', geo-engineering, and other ecogovernance arrangements leave an uncanny remainder? Are we not left with a gnawing feeling that despite the elevation of the ecological condition to the dignity of a global public concern, the socio-ecological parameters keep eroding further? Indeed, while other 'risks', like refugees, terrorists, and financial markets are subject to immuno-biopolitical gestures that promise life unencumbered (for the included and thereby re-producing and expanding the exposed), the environmental bio-political masquerade captured by empty signifiers like 'sustainability', 'adaptation', or 'retroeco-engineering', secures at best a palliative for temporary relief. This palliative operates indeed as a pharmakon, both poison and remedy (Derrida, 1981).

Drawing on Neyrat's use of Lacanian categories (and signified here with capital letters), the insistent intrusion of the Real of socio-ecological destruction, despite the recurrent promises of a 'sustainable' future, undermines terminally this immunological fantasy script, exposes its unstable core, uncovers the gap between the 
Symbolic and the Real, and undermines its supporting Fantasy space and discursive matrix. The emperor is without clothes. The incessant return of the Real of ecological disintegration might fatally undermine our drive's primordial energy as we become increasingly caught up in the horrifying vortex of radical, irreversible and uneven socio-ecological disintegration. The Fantasy of eternal life meets the intrusion of the Real of unavoidable but always premature end. A radical re-imagination of the sociogeo-physical constellation of the earth system was therefore urgently called for, a chance to avoid the unbearable Reality of an untimely death that is now firmly on the horizon. Within this configuration, as Esposito $(2008 ; 2011)$ continues, the immunological biopolitical dispositif turns indeed into a thanatopolitics of who should live or die. Achille Mbembe expands on this by suggesting that the 'make live and let die' of biopolitical governance becomes transfigured under generalized neoliberalization into a necropolitics of let live for the included and make die for the excluded as the central figure of a combined but unevenly triaged immunitary biopolitics (Mbembe, 2013; see also Gržinić, 2016). In the excessive acting of the immunological drive, the dispositif turns against that which it should protect. It becomes self-destructive in a process of auto-immunization. The very mechanisms that permitted biopolitical governance in the $20^{\text {th }}$ century - the thermocene of unbridled carbon metabolization and energy production, combined with the capitalocene of accumulation and mass consumption for the few-turned into an autodestructive process. This auto-immunization process, in turn, isolates the pathological syndrome and treats it as an externalized 'bad' that requires isolation and sequestration (Garcia, 2015: 352-353). In other words, the mechanisms that permit to make and secure life, end up threatening its very continuation [3]. This infernal dialectic, Neyrat argues, is predicated upon re-doubling the fantasy of absolute 
immunization, the fact that despite the fact we know very well we shall die, we act and organize things as if life will go on forever (Neyrat and Johnson 2014). It is precisely at a time when the Real of the excessive acting of an externalized threat, in particular in the form of $\mathrm{CO}_{2}$, cannot any longer be contained and ignored that a widening and intensification of the immunological biopolitical drive is called for (Neyrat 2014). This procedure, in turn, is predicated upon an ontological shift that internalizes the pathological outsider through a relational matrix that renders it 'governable'. For Esposito (2011), such interiorization of the threatening outsider is precisely the key dispositif of immunological techno-governance. This re-doubling of the phantasmagoric desire for absolute immunization deepens a thanato-political autoimmunization process. It is in this fantasy space, sustained by a human exceptionalism as the sole species capable of preventing its own death, that both the modest and more radically accelerationist AnthropoScenes that accompany the inauguration of the Anthropocene find their ultimate ground. The strategy of adaptive and resilient assembling of the human and non-human in an unpredictable and uncertain world, risks deepening this immunological drive (Neyrat, 2014).

The symmetrical human-non-human foundation promises to cut through the unbearable deadlock between immuno- and thanato-politics without really having to alter the historical trajectory of capitalist socio-ecological change. In fact, it deepens it. In psycho-analytical terms, the immuno-biopolitical prophylactic that these AnthropoScenes disclose circulates around the death-drive, the obsessive pursuit of desire that permits covering up the inevitability of death; it is the process that makes sure that we can go on living without staring the Real of eventual (ex-)termination in the eye. While the pursuit of happiness lies in avoiding pain, the death drive, sustained by desire, propels us forward as if we would live forever irrespective of 
(and even moved along by) the threats we encounter on our journey to the end. The energy of the drive is fuelled by the disavowal of a certain death. It is this hysterical position that guarantees that death remains obscure and distant, an obscene impossibility. Fantasy permits covering up this deadlock.

The AnthropoScenic promise of a radically constructivist materialist ontology brings the whole of the earth system within an immuno-biopolitical frame. This would guarantee the sustainability of civilization as we know it and push forward life's drive, while, at the same time, deepening auto-immunological disintegration. Such phantasmagoric staging of the AnthropoScene depoliticizes matters. We can allegedly survive without the necessity of facing radically different political choices; a shift in techno-managerial apparatuses, supported by a particular materialist ontological script, will suffice.

It is in this context that we need carefully to scrutinize the presumably radical ontological edifice in which some of the AnthropoScenes are vested. In the transcendence of the nature-society split promised by introducing a human/nonhuman ontology, the radical otherness upon which relationality is necessarily conditioned is strangely often suspended (with a few notable exceptions that recognize non-human exteriority, see Clark $(2014 ; 2017)$ and Yusoff (2013)). In other words, the move to a relational-materialist ontology sutures things such that the exteriority that undergirds and structures relationality runs the risk of disavowal. To put it simply, the effort to contain and transcend the nature-society split or dualism through ontologies of internal relationality disavows the separation upon which relationality is necessarily constituted. Or, put differently, split does not equate separation (Neyrat, 2016: 266ff). 


\subsection{A Relationality Without Excess}

What needs to be foregrounded, Neyrat (2016) argues, is the exteriority or separation that renders a relationship possible, the recognition that there is a non-reconstructable part of the earth. This exteriority, we maintain, must also recognize the possibilities of excessive acting that cut through the 'people' or the 'human' and express class, gender or other divisions. While the separation of yesteryear is turned into a soldering together of the human and the non-human, the multiple exteriorities that co-define the relational configuration have to be recognized too. This is a gesture comparable to Luce Irigaray's position that the dominant structuring of gender relations, occasionally reproduced by feminist thought itself, renders the female invisible and mute, as the male-dominated configuration defines both man and woman (Irigaray, 1985; see Neyrat and Johnson, 2014). Patriarchy renders woman non-existent, mute, or void. Similarly, the capital-labour relation, whereby capital produces both content and provides substance to the body of the worker, will fully define his or her properties. Feminist or working class politics - the becoming of political subjects - in contrast, resides precisely in the process by which the exteriority of the relationship is affirmed, whereby the separation (not the split) between genders or between capitalists and workers is foregrounded. The immanence of exteriority becomes sensible when women become feminists or workers proletarians, a move by which the relational symmetry that announced the non-existence of the Other is interrupted or subverted by forms of acting, doing, and saying that are subtracted from the existing relational matrix, and cannot any longer be contained within it. Neyrat insists that 'an ecology of separation affirms that without taking distance within a socio-economic situation, no real political decision is possible, no technological choice can really be envisaged' (Neyrat, 2016: 34, our translation). Acting excessive to the bonds and 
bounds of the relationship opens up precisely the gap that defines the political. As we shall argue below, the excessive or supernumerary acting that interrupts, intervenes in, or undermines a relational constellation is precisely where post-foundational political thought discerns the hard kernel of performative political acting and subjectivation (Velicu and Kaika, 2015).

While the one-sided 'modernist' myth of the human-nature split has to be abandoned, the condition of exteriority between and among heterogeneous humans and heterogeneous non-humans has to be recognized and fully endorsed. Without abandoning a relational perspective that transcends the binary split of the naturesociety divide, the focus needs to be squarely on considering the ontology of the relational frame. A relationality that recognizes separation as a condition of possibility for relating different entities to one another requires in turn to insist on the heterogeneous, never fully accountable, never closed, potentially excessive or supernumerary interruptive acting of both humans and non-humans. Or in other words, our human and non-human alliances and networks produce outcomes that are, of necessity, not fully integrated within the relations we mobilize to account for them. There are forms of acting that supersede, transform, and, occasionally, undermine the very stability of the relational configuration. To put it simply, natures as well as humans will continue to act in strange, unaccounted for, excessive manners that preclude the sort of Anthropocenic adaptive control and resilient management some eco-modernizers foreground. It is precisely this excess to the relation, the acting overand-beyond what a relation sustains that will keep haunting and propel the earthsystem in all manner of different, and largely unpredictable, future trajectories. It is within this whimsical acting that sides have to be taken, choices made, and through which political subjectivation unfolds. 
These are the moments and places from where disruptive and revolutionary transformation is enacted. This unsymbolised acting is, in Žižekian terms, the moment of the return of the Real, the violent intrusion of the non-symbolized and nonsymbolizable excessive component, the stain that disrupts the smooth surface and interrupts the state of affairs (Žižek, 1999; 2002). In such moments, the truth of the situation, the properly obscene character of the AnthropoScene is revealed for what it is, merely an already failing attempt of subsuming the newly found socio-natural imbroglios within the intensifying and accelerating circuits of metabolic transformation on which the circulation of capital necessarily rests.

\section{Acting $\neq$ Political Acting: Re-centering the Political}

Where have we arrived in terms of political practice? How can post-foundational political thought help to re-centre the political in a way that embraces the exteriorities of humans and non-humans, while focusing squarely on cutting through decades of de-politicization and neoliberalization? What is a radical democratic practice that moves beyond calls for a multi-species ethics of care and a horizontal-symmetrical pluriverse (Clark, 2014; Hamilton, 2015a)? These are not easy questions to answer and while any formulation would require to be situated and provincialized (Lawhon, Ernstson and Silver, 2014), we believe one possible avenue resides in seeking a political practice that responds to the three-pronged challenge that post-foundational political theory has articulated, a political practice that revolves around the excessive or supernumerary acting that interrupts and undermines any relational constellation [4].

Drawing on a diverse literature (see Marchart, 2007; Wilson and Swyngedouw, 2014), this means, first, to consider political practice to be strictly 
aesthetic and performative. Politics turns around the 'distribution of the sensible,' a police order that can be ruptured through the creation of what Ranciére calls 'a polemical scene' within which what was recorded as noise becomes sensible, hearable, and intelligible (Ranciére, 1998). The political cannot be 'read off' the social order, but arises out of the excess that no relational order can contain. Second, such performative disruption operates through the axiomatic operation of equality when affected bodies, the 'part that has no part' (those who are not accounted for within the existing constellation) demand a rearrangement of the current order-not as a minority to be integrated, but as equals (Ranciére, 1998). This foregrounds, and thirdly, a political practice that maintains, as expressed by Alain Badiou, fidelity to the truth of the interrupting event such that we 'move within the situation that this event has supplemented, by thinking [our tactics and organizational forms] "according to" the event' (Badiou 2012: 41). These formulations do not need legitimization on the basis of an ontology of Nature, whether Anthropocenic or otherwise, but through the interruptive and performative staging of equality (Rancière, 1998, 2013; Marchart, 2007).

There is an increasing interest to re-articulate the political within socioenvironmental and political ecological discourse. Indeed, the exteriority of any relational configuration, one that asserts the possibility for supernumerary acting may be what Jane Bennett understands as the political matter of matter (Bennett, 2010: 106). In drawing on Rancière in particular, others have explored this further. For example, Àvila and Ernstson (2018) examine intimate encounters with poisonous scorpions in bathrooms of Córdoba, Argentina; Cohen (2015) considers escaping zoo animals; and Booth and Williams (2014) articulate 'more-than-human political moments' in relation to wildfires in Australia. These elaborations focus on the ways 
non-humans might be involved in political speech to express equality. While we agree that contingent non-human acting can and does participate in 'an anarchic disruption of function and place, a sweeping de-classification of speech' (Booth and Williams, 2014: 186, citing Hallward, 2003: 192), these perspectives seem to ignore that such disruptions need also to be viewed as taking place within, or are strongly related to, the wider immuno-political dispositif that we outlined above. Rather than weakening the immunitary logic, these more-than-human disruptions are exactly the kind of anxiety-filled disruptive events that immunitarian responses feed off. So, while natures' heterogeneous acting might interrupt the smooth functioning of anthropocentric ontologies and human-nonhuman imbroglios-from hurricanes reordering people and things, nuclear reactors blowing up, GMOs rekindling DNA, or new virus strains emerging - it is also this excessive performativity that nurtures concerns with risks and immunization. Simply put, rather than undermining an immunitary logic, they could strengthen modes, mechanisms, and subjectivities of auto-immunization. As argued above, it is precisely in the aftermath of such disruptive events that the immuno-biopolitics of the Anthropocene may perform its most obscene work, the impossible promise that 'humanity' could indeed manage the earth system or even local ecosystems without altering the matrix of existing socioecological relations.

The political practice we are searching for then, needs to make 'a wager' on natures, to articulate and force political choices between this rather than that nature. In doing so, dissensual axes are clarified, lines are drawn and possible future trajectories charted. A re-emergence of the political resides in fidelity, manifested in militant acting, to egalitarian political events that might open a political truth procedure. This involves the emergence of political subjects that maintain a fidelity to the inaugural 
egalitarian event and aspire to its generalization through sustained actions (Badiou, 2007). With these criteria in mind, we find inspiration (albeit not without reservations) in struggles over land-use like the one against the Keystone XL Pipeline in the USA that brought together diverse groups in disciplined action; but also in militant Andean mobilizations against resource extraction that created, as expressed by De la Cadena (2015: 3), a mise-en-scène that challenges 'the transformation of territories into grounds for investment $[\ldots]$ into a relentless demand for politics that reveals, to paraphrase and tweak Rancière, the presence of many worlds being forced into one.'

But it is also imperative to be inspired by supposedly less 'environmental' struggles: the Syntagma Square protests, the Indignados, Occupy!, Black Lives Matter, the feminist-based Kurdish Rojava communes. Beyond their aspirations to rupture the individualistic and immunological hard kernel of neoliberalism, they are also and always political-ecological, producing alternative socio-ecological relations that scholars and activists need to engage with. They help to provoke the question how militancy, fidelity to the egalitarian event, and the production of new socionatures might be welded together. In the midst of the Rhodes Must Fall movement in South Africa, writer-activist Leigh-Ann Naidoo spoke of the 'genius' of student-and-worker militancy:

[The task is] to kill the fallacies of the present. [... ] To arrest the present. To stop it. To not allow it to continue to get away with itself for one more single moment. [...] There has to be a measure of shut down in whatever form, for the future to be called. (Naidoo, 2015: 2) 
This resonates profoundly with the tactics and militancy required to transform a depoliticized neoliberal-ecological order. The political re-appears here in the fidelity to the practical possibility of the coming community, but without ultimate ontological guarantee in history, geography, Nature, the Party, or the State (Badiou, 2007). Offstaged by so many storylines and narratives, including the AnthropoScenes, the political has to be militantly on-staged as an egalitarian possibility in the here and now. To slowly and relentlessly carve out a new socio-physical reality, often in the face of the most formidable repression and violence, requires continuous political labour and a collective genius, sustained by militant action, painstaking organization and above all, abandoning the fear of failing as failing we shall; more-than-human unpredictability guarantees that. Yet, in radically embracing the exteriorities of the socionatural world, we know from history and everyday experience that more egalitarian ways of being-in-common stand in waiting to be realized.

\section{Conclusion}

Placing our notion of the Anthropo-obScene in an uncanny relation to the now popularized term of the Anthropocene, we have attempted to explore the potential depoliticizing processes that accompany the controversies over the Anthropocene and to suggest possible trajectories for re-politicization. Rather than a socio-ecological and historico-geographical description of our situation, as in Moore's Capitalocene (2015; 2016), or in departing from the life-generating co-becomings of Haraway's critters in the Chthulucene, we have developed a post-foundational political perspective that rests on the idea of the political as performative acting, the moment when those who are not counted disrupt the state of the socio-ecological order. We explored how a set of presumably radical ontological narratives risk silencing or off-staging the 
supernumerary and excess upon which relationality is necessarily conditioned. This does not in any way suggest ignoring, let alone forgetting, the Real of natures or, more precisely, the diverse, multiple, whimsical, contingent and often unpredictable socio-ecological relations of which we are part. The claim we make is about the urgent need to question the legitimacy of all manner of socio-environmental politics, policies, interventions, and relational ontologies that disavows the constitutive split of the demos by erasing the spaces of agonistic encounter (Mouffe, 2005). The above reconceptualisation urges us to accept the extraordinary variability of natures, insists on the need to make 'a wager' on natures. To the extent that there is an earthly politics, it will have to be one that attests to the heterogeneities that cut through the social, destabilize any community, interrupts the order of the sensible, subtracts from the relational frame, and — in doing so - proposes and works through forging new egalitarian human-nonhuman entanglements.

\section{Endnotes}

[1] It is common to refer to C.S. Holling's 1973 essay in theoretical ecology as the foundational paper of non-equilibrium theory. This fails to recognize earlier developments and, in particular, Richard Lewontin's 1969 essay where he developed non-equilibrium ecology on which Holling built. To mention the latter and not the former is an oft-repeated misrepresentation of history in theoretical ecology, somewhat surprisingly repeated by Bonneuil and Fressoz (2016), Braun (2015), and Nelson $(2014 ; 2015)$. The correction is important since Lewontin went on to develop, with Richard Levins, a dialectical, Marxist and historical interpretation of nonequilibrium ecology (Lewontin and Levins, 1985), while Holling, in contrast, 
advanced a strikingly managerial and depoliticizing version in the guise of "resilience thinking" (Folke, 2006), what Nelson (2014) aptly named "[r]esilience and the neoliberal counterrevolution."

[2] For a review, see Hamilton (2013). Interestingly, there is also a Marxist variation of the accelerationist world-view, see, for example, Williams and Srnicek (2013).

[3] Indeed, capitalism, interlinked with, constituted by and enmeshed with colonialism, imperialism and patriarchy, has from its inception exploited women, men, children, soils, forests, animals, seas, lakes, DNA, bacteria etc., to secure a good life for the few. Many scholars have accounted for this, see for instance: Douglass (1986 [1845]); Marx (1967 [1867]); Fanon (1963 [1961]); Haraway (1991); Federici (2004); and Moore (2015).

[4] Post-foundational political thought emerged among continental European thinkers from the 1970s in a response to the crisis and failure of state-centered socialism and structural Marxism (Marchart, 2007; Swyngedouw, 2011). It developed in the same decades as both complexity science and new materialist ontologies, but with little mutual recognition.

\section{Acknowledgements}

We thank three anonymous reviewers and the journal editor for constructive comments that helped to improve the clarity of our argument. We acknowledge the UK's Economic and Social Research Council (Grant ref: ES/M009408/1; TLR). The 
second author also acknowledges support from the Swedish Research Council Formas (Dnr: 211-2011-1519; MOVE) and The Marcus and Amalia Wallenberg Foundation.

\section{Biographies}

Erik Swyngedouw is Professor of Geography at the University of Manchester. He was previously Professor of Human Geography at the University of Oxford. He is author of Liquid Power (MIT Press, 2015) and Promises of the Political (MIT Press, 2018).

Henrik Ernstson is Lecturer in Human Geography at The University of Manchester and Research Fellow at the KTH Royal Institute of Technology. He has been a longtime Visiting Scholar at the African Centre for Cities at the University of Cape Town and he was from 2013 to 2015 a Stig Hagström Postdoctoral Fellow at the Department of History at Stanford University.

\section{References}

Arendt, Hannah (1958) The Human Condition. Chicago: Chicago University Press. Àvila, Martìn and Ernstson, Henrik (2018, forthcoming) Realms of exposure: Design and speculation with more-than-human political moments. In Ernstson, Henrik and Sörlin, Sverker (eds) Grounding Urban Natures: Histories and Futures of Urban Ecologies. Cambridge: MIT Press

Barnett, Lydia (2015) The theology of climate change: Sin as agency in the Enlightenment's Anthropocene. Environmental History 20: 217-237. Badiou, Alain (2007) Live Badiou: Interview with Alain Badiou, Paris 2007. In Feltman, Oliver (ed) Alain Badiou: Live Theory. London: Continuum, pp. 
$130-139$.

Badiou, Alain (2008) The communist hypothesis. New Left Review 49: 29-42.

Badiou, Alain (2012) Ethics: An Essay on the Understanding of Evil. London: Verso.

Bakker, Karen (2004) An Uncooperative Commodity. Privatizing Water in England and Wales. Oxford: Oxford University Press.

Bennett, Jane (2010) Vibrant Matter: A Political Ecology of Things. Durham: Duke University Press.

Biermann, Frank (2007) Earth System Governance as a crosscutting theme of Global Change Research. Global Environmental Change 17: 326-37.

Biermann, Frank, Abbott K, Andresen S, et al. (2012) Navigating the Anthropocene: Improving Earth System Governance. Science 335: 1306-07.

Bonneuil, Christophe and Fressoz, Jean-Baptiste (2013) l'Evénement Anthropocène: La Terre, l'Histoire et Nous. Paris: Seuil.

Bonneuil, Christophe and Fressoz, Jean-Baptiste (2016) The Shock of the Anthropocene. London: Verso.

Booth, Kate, and Williams, Stewart (2014) A more-than-human political moment (and other natural catastrophes). Space and Polity 18(2): 182-95.

Brand, Stewart (2009) Whole Earth Discipline: An Ecopragmatist Manifesto. New York: Viking.

Braun, Bruce (2015) New materialisms and neoliberal natures. Antipode 47(1):1-14.

Brossat, Alain (2003) La Démocratie Immunitaire. Paris: La Dispute.

Castree, Noel (2014a) The Anthropocene and geography I: The back story. Geography Compass 8: 436-49.

Castree, Noel (2014b) Geography and the anthropocene II: Current contributions. Geography Compass 8: 450-63. 
Castree, Noel (2014c) The Anthropocene and geography III: Future directions. Geography Compass 8: 464-78.

Chakrabarty, Dipesh (2009) The climate of history: Four theses. Critical Enquiry 35: $197-222$.

Chakrabarty, Dipesh (2017) The politics of climate change is more than the politics of capitalism. Theory, Culture and Society. 34(2-3): 25-37.

Clark, Nigel (2014) Inhuman Nature: Sociable Life on a Dynamic Planet. London: Sage.

Clark, Nigel (2017) Politics of strata. Theory, Culture and Society. 34(2-3): 211-31.

Coole, Diana H and Frost, Samantha (eds) (2010) New Materialisms: Ontology, Agency, and Politics Durham, NC: Duke University Press.

Cronon, William (1992) A place for stories: Nature, history and narrative. The Journal of American History 78(4): 1347-1376.

Crutzen, Paul (2002) Geology of mankind. Nature 415: 23.

Dalby, Simon (2017) Anthropocene formations: Environmental security, geopolitics and disaster. Theory, Culture and Society. 34(2-3): 233-52.

De la Cadena, M (2015) Uncommoning nature. E-Flux Journal, 65: 1-8.

Demos, TJ (2015) V. Anthropocene, Capitalocene, Gynocene: The many names of resistance. In: Still Searching. Available at: http://blog.fotomuseum.ch/2015/06/v-anthropocene-capitalocene-gynocenethe-many-names-of-resistance/. Accessed 20 February 2017.

Derrida, Jacques (1981) Plato's pharmacy. In: Dissemination. London: The Athlone Press, pp. 61-172.

Douglass, Frederick (1986 [1845]) Narrative of the Life of Frederick Douglass, an American Slave. New York: Penguin. 
Eckersley, Robyn (2017) Geopolitan democracy in the Anthropocene. Political Studies. Doi: 10.1177/0032321717695293.

Ellis, Erle (2011) The planet of no Return: Human resilience on an artificial earth. The Breakthrough Journal 2: 37-44.

Ellis, Erle, Maslin, Mark, Boivin, Nicole and Bauer, Andrew (2016) Involve social scientist in defining the Anthropocene. Nature 540: 192-193.

Esposito, Roberto (2008) Bios: Biopolitics and Philosophy. Minneapolis: University of Minnesota Press.

Esposito, Roberto (2011) Immunitas. Cambridge: Polity Press.

Fanon, Frantz (1963 [1961]) The Wretched of The Earth. New York: Grove Press.

Federici, Sylvia (2004) Caliban and the Witch: Women, the Body, and Primitive Accumulation. New York: Autonomedia.

Fressoz, Jean-Baptiste and Locher, Fabien (2010) Le climat fragile de la modernité. Petite histoire climatique de la réflexivité environnementale. In: La Vie des Idees. Available at: http://www.laviedesidees.fr/Le-climat-fragile-de-lamodernite.html. (accessed 10 August 2016).

Fressoz, Jean-Baptiste and Locher, Fabien (2012) Modernity's frail climate: A climate history of environmental reflexivity. Critical Inquiry 38(3): 579-598.

Galaz, Victor (2012) Geo-engineering, governance, and social-ecological systems: Critical issues and joint research needs. Ecology and Society 17: 24.

Garcia, Pierre-Olivier. 2015. Sous l'Adaptation, l'Immunité. Etude sur le Discours de l'Adaptation au Changement Climatique. PhD Dissertation, Université Grenoble Alpes.

Gržinić, Marina (2016) 'Afterwards': Struggling with bodies in the dump of history. In: Jiménez del Val, Nasheli (ed) Body between Materiality and Power: 
Essays in Visual Studies. Newcastle upon Tyne: Cambridge Scholars Publishing, pp. 163-182.

Hamilton, Clive (2013) Earthmasters: The Dawn of the Age of Climate Engineering. London: Yale University Press.

Hamilton, Clive (2015a) Human Destiny in the Anthropocene. In: Hamilton, Clive, Bonneuil, Christophe and Gemenne, Francois (eds) The Anthropocene and the Global Environmental Crisis - Rethinking modernity in a new epoch. London: Routledge, pp. 32-43.

Hamilton, Clive (2015b) The theodicy of the 'good Anthropocene'. Environmental Humanities 7: 233-238.

Hamilton, Clive, Bonneuil, Christophe, and Gemenne, Francois (eds) (2015) The Anthropocene and the Global Environmental Crisis. New York: London. Haraway, Donna (1991) Simians, Cyborgs, and Women: The Reinvention of Nature. New York: Routledge.

Haraway, Donna (2016) Staying with the Trouble: Making Kin in the Chthulucene. Durham. N.C.: Duke University Press.

Harman, Graham (2016) Immaterialism: Objects and Social Theory. Cambridge: Polity Press.

Holling, Crawford S (1973) Resilience and stability of ecological systems. Annual Review of Ecology and Systematics 4(1): 1-23.

Hornborg, Alf (2009) Zero-sum world: Challenges in conceptualizing environmental load displacement and ecologically unequal exchange in the world-system. International Journal of Comparative Sociology 50(3-4): 237-262.

Irigaray, Luce (1985) The Sex that is not One. Ithaca: Cornell University Press. Kaika, Maria (2017) Between compassion and racism: How the biopolitics of 
neoliberal welfare turns citizens into affective 'idiots'. European Planning Studies, DOI: 10.1080/09654313.2017.1320521.

Latour, Bruno (2005) Reassembling the Social: An Introduction to Actor-NetworkTheory. Oxford: Oxford University Press.

Latour, Bruno (2011) Love your monsters: Why we must care for our technologies as we do our children. Breakthrough Journal Fall: 19-26.

Latour, Bruno (2015a) Face à Gaïa: Huits Conférences sur le Nouveau Régime Climatique. Paris: La Découverte.

Latour, Bruno (2015b) Fifty shades of green: Bruno Latour on the Ecomodernist Manifesto. Available at: https://entitleblog.org/2015/06/27/fifty-shades-ofgreen-bruno-latour-on-the-ecomodernist-manifesto/ (accessed 1 March 2017).

Latour, Bruno (2017) Why Gaia is not a god of totality, Theory, Culture and Society 34(2-3): 61-81.

Lawhon, Mary, Ernstson, Henrik and Silver, Jonathan D (2014) Provincializing Urban Political Ecology: Towards a Situated UPE through African urbanism. Antipode, 46(2): 497-516.

Lewis, Simon L and Maslin, Mark (2015) Defining the Anthropocene. Nature 519: $171-80$.

Lewontin, Richard C (1969) The meaning of stability. Brookhaven Symposia in Biology 22: 13-23.

Lewontin, Richard C and Levins, Richard (1985) The Dialectical Biologist. Harvard: Harvard University Press.

Lorimer, Jamie (2016) The Anthropo-scene: A guide for the perplexed. Social Studies of Science (1): 117-142.

Lorimer, Jamie and Driessen, Clemens (2014) Wild experiments at the 
Oostvaardersplassen: Rethinking environmentalism in the Anthropocene. Transactions of the Institute of British Geographers, 39(2):169-181.

Malm, Andreas and Hornborg, Alf (2014) The geology of mankind? A critique of the Anthropocene narrative. The Anthropocene Review 1(1): 62-69.

Marsh, George P (1864) Man and Nature; or, Physical Geography as Modified by Human Action. Scribners, and reprinted by The Belknap Press of Harvard University Press: New York.

Marsh George P (1874) The Earth as Modified by Human Action: A New Edition of 'Man and Nature' Scribner, Armstrong and Co., and reprinted by Arno Press: New York.

Marchart, Olivier (2007) Post-foundational Political Thought: Political Difference in Nancy, Lefort, Badiou and Laclau. Edinburgh: Edinburg University Press.

Marx, Karl (1967 [1867]) Capital. Volume 1. New York: International Publishers. Marx, Karl (1959 [1844]) Economic and Philosophic Manuscripts of 1844. Moscow: Progress Publishers.

Mbembe, Achille (2003) Necropolitics. Public Culture 15(1): 11-40.

Moore, Jason W (2015) Capitalism in the Web of Life: Ecology and the Accumulation of Capital. London: Verso.

Moore, Jason W (ed) (2016) Anthropocene or Capitalocene: Nature, History and the Crisis of Capitalism. Oakland: PM Press.

Morton, Oliver (2015) The Planet Remade: How Geoengineering Could Change the World. Princeton, NJ: Princeton University Press.

Morton, Timothy (2013) Hyperobjects: Philosophy and Ecology After the End of the World Minneapolis: University of Minnesota Press.

Mouffe, Chantal (2005) On the Political. London: Routledge. 
Nadasdy, Paul (2007) Adaptive co-management and the gospel of resilience. In: Armitage, Derek, Berkes, Fikret, and Doubleday Nancy (eds) Adaptive CoManagement: Collaboration, Learning and Multi-Level Governance. Vancouver: UBC Press, pp. 208-227.

Nelson Sara H (2014) Resilience and the neoliberal counterrevolution: From ecologies of control to production of the common. Resilience 2(1): 1-17.

Nelson, Sara H (2015) Beyond the limits to growth: Ecology and the neoliberal counterrevolution. Antipode 47(2): 461-480.

Neyrat, Frédéric (2008) Biopolitique des Catastrophes. Paris: Les Prairies Ordinaires. Neyrat, Frédéric (2010) The birth of immunopolitics. Parrhesia 10: 31-38.

Neyrat, Frédéric (2014) Critique du géo-constructivisme Anthropocène and géoingénierie. Multitudes, 56. Available at: http://www.multitudes.net/critiquedu-geo-constructivisme-anthropocene-geo-ingenierie/ (accessed 1 July 2017). Neyrat Frédéric (2016) La Part Inconstructible de la Terre. Paris: Editions du Seuil. Neyrat, Frédéric, and Johnson, Elisabeth (2014) The political unconscious of the Anthropocene: A conversation with Frédéric Neyrat. Society and Space Open Site. Available at: https://societyandspace.com/material/interviews/neyrat-byjohnson/ (accessed 30 May 2017).

Parenti, Christian (2011) Tropic of Chaos: Climate Change and the New Geography of Violence. New York: Nation Books, 2011

Pellizzoni, Luigi (2015) Ontological Politics in a Disposable world: The New Mastery of Nature. Farnham: Ashgate.

Pellizzoni, Luigi (2016a) Catching up with things? Environmental sociology and the material turn in social theory. Environmental Sociology 2(4): 312-321.

Pellizzoni, Luigi (2016b) Speeding up, slowing down: On the critical limits of 
nondualist ontologies. Paper presented at the 3rd ISA Forum of Sociology: The Futures We Want: Global Sociology and the Struggles for a Better World. 10-14 July, Vienna. Available at: https://isaconf.confex.com/isaconf/forum2016/webprogram/Paper81032.html (accessed 9 August 2017).

Protevi, John (2013) Life, War, Earth: Deleuze and the Sciences. Minneapolis: University of Minnesota Press.

Rancière, Jacques (1998) Disagreement. Minneapolis: University of Minnesota Press. Rancière, Jacques (2013) The Politics of Aesthetics. London: Bloomsbury Academic. Shellenberger, Michael, and Nordhaus, Ted (2007) Break Through: From the Death of Environmentalism to the Politics of Possibility. Boston, MA: Houghton Mifflin Co.

Shellenberger, Michael and Nordhaus, Ted (eds) (2011) Love Your Monsters: Postenvironmentalism and the Anthropocene. Oakland, CA: The Breakthrough Institute.

Sherlock, Robert L (1922) Man as a Geological Agent: An Account of His Action on Inanimate Nature. London: H.F. and G. Witherby.

Steffen, Will, Grinevald, Jacques, Crutzen, Paul and McNeill, John (2011a) The Anthropocene: conceptual and historical perspectives. Philosophical Transactions of the Royal Society A: Mathematical, Physical and Engineering Science 369: 842-867.

Steffen, Will, Persson, Åsa, Deutsch, Lisa et al. (2011b) The Anthropocene: From global change to planetary stewardship. Ambio 40: 739-761.

Stengers, Isabelle (2003) Cosmopolitiques. Paris: La Découverte.

Swyngedouw, Erik (2011) Interrogating post-democracy: Reclaiming egalitarian 
political spaces. Political Geography 30: 370-380.

Swyngedouw, Erik (2016) La Naturaleza No Existe. Puenteaéro Ediciones, Buenos Aires. Buenos Aires: Puenteaéro Ediciones.

The Royal Society (2009) Geoengineering the Climate: Science, Governance and Uncertainty. London: The Royal Society.

Tsing, Anna L (2015) The Mushroom at the End of the World. Princeton: Princeton University Press.

Velicu, Irina and Kaika, Maria (2015) Undoing environmental justice: Re-imagining equality in the Rosia Montana Anti-mining Movement. Geoforum 84: 305 315.

Vernadski, Vladimir (1926) La Biosphère. Paris: Félix Alcan.

von Heland, Jacob and Sörlin, Sverker (2012) Works of Doubt and Leaps of Faith: An Augustinian Challenge to Planetary Boundaries. Journal for the Study of Nature, Religion, and Culture 6(2): 151-175.

Walker, Jeremy and Cooper, Melinda (2010) Genealogies of resilience: From systems ecology to the political economy of crisis adaptation. Security Dialogue 42(2): $143-160$.

Wilson, Japhy and Swyngedouw, Erik (eds) (2014) The Post-Political and its Discontents. Edinburgh: Edinburgh University Press.

Yusoff, Kathryn (2013) Geologic life: prehistory, climate, futures in the Anthropocene. Environment and Planning D: Society and Space 31: 779-395. Yusoff, Kathryn (2017) Geosocial strata. Theory, Culture and Society. 34(2-3): 10627.

Žižek, Slavoj (1999) The Ticklish Subject: The Absent Centre of Political Ontology. London: Verso. 
Žižek, Slavoj (2002) Welcome to the Desert of the Real. London: Verso. 